


\title{
BAIXIOS DE VIADUTOS ${ }^{1}$
}

\author{
UNDER THE VIADUCTS
}

\author{
Adrienne O. Lessa \\ Flávio Agostini² \\ Luciana Miglio \\ Margarete Maria de Araújo Silva ${ }^{3}$ \\ Mateus Gouvêa de Sousa
}

\section{Resumo}

O objetivo básico do projeto "Baixios de Viadutos" é lançar um plano de programas, com fins de implantação real, para áreas lindeiras a 12 viadutos e 3 passarelas de pedestres ao longo de 15 quilômetros de extensão da Via Expressa Leste-Oeste, em Belo Horizonte. Trata-se de áreas ociosas, nunca vistas como locais com potencial de ocupação planejada.

Palavras-chave: Viadutos; Crescimento informal; Áreas lindeiras.

\begin{abstract}
The purpose of the project "Under the Viaducts" is to launch a plan with the intention of really implementing, for a specific areas over nine miles from the East-West Expressway, in Belo Horizonte. These are idle areas, never seen as potential sites of planned occupation.
\end{abstract}

Keywords: Viaducts, informal growth, bordering areas. 